The stimulating effects of thyroid hormones on several enzymatic functions have been recognized (1.3). Whether they play a major role in the maturation of the ensmatic apparatus of lung surfactant remains to be demonstrated. Therefore, an etiologic role of thyroid defieiency in RDS camnot be considered and the association may be regarded as coincidental or possibly consequential. A defieiency of thyroid hormones, albeit relative and transient. may produce adverse conseyuences in a critical period of ecrebral maturation. At present. howerer, the extent and the nature of such possibility remains conjectural. From the observations of $\mathrm{T}_{3}$ changes in healthy preterm infants it appears that the birth-triggered increase in peripheral monodeiodination of $T_{4} 10 T_{3}$ requires a gestational age-dependent matturational process. These limited observations emplatsie the need for further evaluation of the role of thyroid hormones in RDS and in the early postnatal development of preterm infants.

\section{CONCLUSION}

A significant difference in the postnatal $\mathrm{T}_{3}$ concentrations of healthy preterm infants compared to full term infants has been described. In preterm infants with RDS the immediate postnatal $T_{3}$ rise is lacking and abnormally low levels of $T_{3}$ persist up to 3 wects of age. The difference in the postnatal $T_{3}$ concentration of healthy preterm inlants from the pattern observed in healthy full term infants can be explated on the basis of thyroid immaturity but the mechanism of the prolonged hypotriedothyroninemia in babies with RDS remains to be clucidated.

\section{RIFERIN(IS AND NOTHS}

1. Abuid, J., Stinsen, D. A. and Larsen, P. R.: Scrum triigdenthyronine and thyroxine in the neonate and the acute increase in these hormones following delivery. J. (lin. Invest.. 52: 1195 (1973).

2. Bermede. F. Surks. 11. 1., and ()ppenheimer. J. H.: High incidence of decreased serum triiedothyronine concentration in patients with nonthyrer idal disease. J. Clin. Endecrimel. Netab.. fl: 27 (1975).

3. Clapra, I. J.. Chopra, U.. Smith, S. R.. Rera, M.. and Solumon, D. H.: Reciprocal changes in scrum concentrations of $3.33^{\prime} .5^{\prime}$-triodedhyronine (reverse $T_{3}$ ) and $3.3^{\prime}, 5$-triedetlyomine $\left(T_{3}\right)$ in systemic illnesses. J. ( lin. Indocrinol. Metab.. $41: 1043(1975)$

4. Cheprat, J.. and Cramdall. B. F.: Thyroid hormones and thyoutropin in am- niotic fluid. N. Engl. J. Mcd.. 293: $740(1975)$

5. Cuestas, R. A., lindall. A.. and Engel. R. R.: Low throvid hormenes and respiratory-distress syndrome of the newborn: studies an cord blowd. $N$ Eng̣l. J. Med.. 245: 297 (1976).

6. Cornichow, P.. Gicenberg, A. H., Tyson, J., and Blizard, R. M.: Thyroid function studies is paired maternal cord sera and seguential obervations of thyrotropic hormone release during the first 72 hours of life. Pediat. Res., 5: 5.3 (1971).

7. Dubouitz. L. M. S.. Dubowite. V... and (ioldherg. C.: Clinicial ansessment of gestational age in the newburn infant. J. Pediat. 77: I (1970).

s. Erenberg. A.. Phelps, D. L.. Lam, R., and Fisher, D. A.: Total and frece thyroid hormone concentrations in the neonatal period. Pediatries, 53: 211 (1974).

9. Fisher. D. A.. and Odell. W. D.: The acute release of thyrotropin in the neuburn. J. (lin. Invest.. As: 1670)(1960).

10. Fisher. D. A.. ()dell. W. D.. and Hobel. ( . J.: Thyroid function in the term fetus. Pediatrich, t4: $526(1960)$

11. Hisher. D. A.. Dussault. J. H., Hohel. (. J., and Lam. R.: Scrum and thy ruid gland triiodetheronine in the human fetus. J. Clin. Enderinol. Metah...36: $307(147.3)$

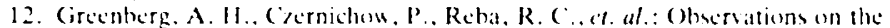
maturation of thyond function in early fetal life. J. (lin. Invest. 49: 1790) $(197(1)$.

13. Hoch. F: Biochemical attions of thy roid hormones. Physol. Rex.. $\$ 2: 605$ (1)62).

14. Latsen. P. R.: Direct immunuthesy of triikdothyronine in human serum. J. (lin. Invest.. 51: 1939 (1972).

15. Man, B. B.. Adelman. M.. Jones. W. S.. and I.ord. R. M.: I cevelopment and B1:I of full term and low birth weight infants through 1 is month. Amer. J. Dis. Child.. 119: 295 (1970)

16. Murphy. B. E. P.. Pattce. ('. J. and Gold. A.: ( linical evaluation of a new methed for the determination of serum thysoxince. J. Clin. Endecrinol. Netiab.. 26: $247(1966)$.

17. Pallel, Y. C., Burger, H. G., and Hudson. B.: Radioimmunoassaty of serum thyoutropin sensitivity and specilicity. J. (Cin. Indecrinol. Netab., 3.3: 768 (1)71).

18. Redding. R. A.. and Pereira. (. Thyroid function in reypiratory distress syndrome of the newhorn. Pediatrics, 54: $\$ 23(1974)$.

19. The fechnical assistance of Mls. (itrolyn Aldridge and sceretarial assistance of Ms. Mary LE. Holroyd is greatly appreciated.

20. This rescarch was presented at the annual mecting of the Southern Socicty of Pediatric Rescarch. New Orleams. Louisiana. Jamuary 1976.

21. This rescarch was supported in part by Public Health Service (irant RR 536011. the Herman Coldman Foundation and National Institutes of Heillh (irant 5 M(O)!-RR-(0)(0)6(0-13.

22. Recuests for reprints should be addressed to: V. Abbassi. M.D., Department of P'ediatrics. (icorgotoun I'nicersty Hosptal. Washington. D).C. (LSA).

23. Received for publication 11ay 21, 1976.

24. Accepted for putlication November"9. 1976
Amino acids carbohydrates dict intestinal development maternal nutrition neonatal development

\title{
Effect of Maternal Protein Deprivation on the Development of Neonatal Intestinal Function in Rats
}

\author{
LOUTTHA D. FERDINANDUS AND JOSFPH F. FT\%GIRALD

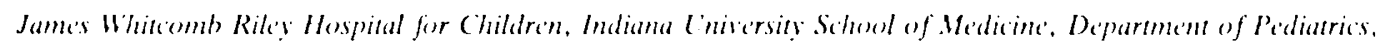 \\ Gastroninestinal Discase Section, Indianapolis, Indiana, U/SA
}

\begin{abstract}
Summary
The developmental pattern of in vitro intracellular accumulation (IA) was studied in the smalt intestine of the offspring of females fed a $27 \%$ protein diet (normal) (NPI) animals) and the offspring of females fed an $8 \%$ protein diet (low) (LPI) animals).
\end{abstract}

At 2 days of age, the $I A$ of L-leucine (Leu) and D)-galactose (Gal) was significantly reduced in the intestines of the I.PI) animals as compared to the NPI) animals at initial velocities $(75 \%$ and $81 \%)$ and under steady state conditions $(82 \%$ and 84\%). The $I A$ of both compounds in the intestines of the LPI) animals increased relative to the NPI) animals until at weaning 
the IA of Leu and Gal under steady state conditions was significantly greater in the I,PD animals $(139 \%$ and $133 \%)$. After weaning, the $I A$ of Leu was statistically increased (137\%) and the $I A$ of Gal was the same in the L.PI) animals as compared to the NPD animals at initial velocities. The variations in the developmental patterns of the $I A$ of $L$.eu and Gal in the intestines of LPI) animals as compared to NPD animals appear to be related to animal age, which may reflect an improved caloric intake at weaning.

\section{Speculation}

Developing rats from females fed an $8 \%$ protein diet demonstrated an increase in intestinal absorption during the weaning period as compared to rats from females fed a $27 \%$ protein diet. This may reflect accelerated gut maturation manifested by an increase in gut size, cell numbers, and transport sites relative to an improved caloric intake associated with the availability of solid food.

The association between poor maternal nutrition and retarded fetal and postnatal growth has been well established $(15,22$. 25). Maternal malnutrition has been shown to delay the development and maturation of the gastrointestinal tract in the offspring $(16,24)$. The absorption of nutrients is known to be impaired in protein and protein-caloric malnourished children (9.10, 17). and in diet-restricted human voluntecrs (1). In a study by Younoszai and Lynch (23), the total amount of hexose absorbed from the perfused gut of growth-retarded suckling rat pups was observed to be less than that of control animals. The authors felt that their data were biased by a reduction in the size of the intestine of the undernourished pups and that rates of absorption (milligrams per g dry wt per hr) were equal or even greater in the growth-retarded animals. Wapnir and Lifshity (1s) have demonstrated a selective alteration of amino acid transport in protein-restricted wealing rats when compared to control animals, i.e., the transport rates of leucine and tyrosine were increased. Whereas the transport rates of phenglalanine and glycine were unaltered and the transport rate of lysine decreased. These data tend to discount thickness of the intestinal wall or overall intestinal size as the sole factor in determining uptake rates in the perfused gut. Studies in our laboratories have shown the intracellular accumulation of L-leucine and D-galactose to be decreased in the 2-day-old progeny of females fed an $8 \%$ protein diet as compared to the progeny of females fed a $27 \mathrm{cos}^{\prime}$ protein diet (6). As an extension of these studies, we have examined the functional development (from 2 days of age to $28-$ 30 dass of age) of the intestines of the offspring of females fed a low protein diet. The results are expressed as intracellular accumulation of L-feucine and D-galactose and compared to data obtained from the offspring of females fed a normal protein diet.

\section{MATERIALS AND METHODS}

White female and male Wistar-strain rats (26) were used in all experiments. A stock laboratory diet (27) was fed to the rats pror to breeding. The animals were mated and mantaned in wire-bottomed catges and fed a $27 \%$ protein dict (normal) or an $8 \%$ protein diet (low) (28). The diets were isocaloric and were administered in pellet form. The composition and energy values of these diets are shown in Table 1 . The pregnant females were placed in individual solid-bottomed breeding calges 2-3 days before parturition. Pups were left with dams until the time of death or until weaning at 20 diys. After weaning. pups received the same diet as their dams. The number of pups per litter was reduced to eight shortly after birth in order to minimize variation due to litter size. The progeny of females fed the $27{ }^{\prime \prime}$ protein diet (normal) are subsequently designed NPI) rats and those of females fed the s"' protein diet (low) as LPI) rats.

Animals were killed at 2,8,9, 14, 15, 16, 20, 21, 28, 29, and 30 days of age. Data from 8 - and $9-; 1+-, 15-$, and $16-.2(1)-$ and
Table 1. Composition (grams per kg) of diets used

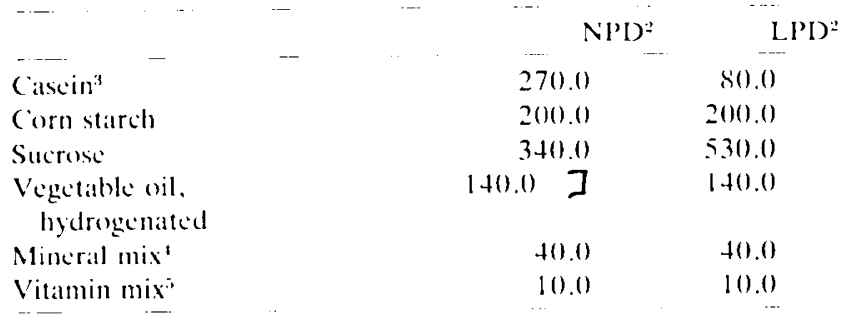

1 Dicts provide approximately $+.5 \mathrm{Kcal} / \mathrm{g}$.

" NPD: $27 \%$ protein dict (normal control): LPD): s\% protein dict (low).

"GiBl, high protein.

'From Bernhart. F. W.. and Tomarelli. R. M.: J. Nutr., s'9: 495 (1960).

: GBBI \#+0060) (milligrams per kg diet): p-aminobensoic acid, 110.1: ascorbic acid, 1016.6; biotin. (0.4; calcium pantethenate, 66.1: choline dihydrogen citratc, $3711 \%$ \% folic acid. 2.0; $i$-inositol, 110.1 : menadione, 49.6; nacin, 99.1; pyridexinc hydrochloride, 22.1; riboflavin, 22.1: thiamine hydrochloride. 22.1; and vitamin 1312 29.7; retinyl palmitate, $20.0 \mathrm{IU} / \mathrm{g}$ diet; ergocalcificol. $2.2 \mathrm{IU} / \mathrm{g}$ diet: and tocopheryl acetate, 0.1 $\mathrm{IU} / \mathrm{g}$ dict.

21-, and 28-. 29-, and 30-day-old animals were combined. The animals were killed by decapitation and the small intestines quickly removed and placed in oxygenated saline. The intestines were split longitudinally while immersed in saline, yiclding segments essentially free of luminal contents. The entire small intestine was used in the studies of 2-day-old animals. Four- to 5 -cm segments from the older animals were used.

The segments were incubated in an oscillating water bath for 5.15 , or $30 \mathrm{~min}$, in $5 \mathrm{ml}$ of an oxygenated Krebs-Ringer-l'ris buffer, pH 7.4. consisting of $118 \mathrm{mill} \mathrm{NaCl}, 25 \mathrm{mil}$ Tris-HCl, $4.7 \mathrm{mM} \mathrm{KCl}, 2.5 \mathrm{mMl}\left(\mathrm{aCl}_{2}, 1.2 \mathrm{mMl} \mathrm{MgSO}\right.$, and $1.2 \mathrm{mM}$ $\mathrm{KH}_{2} \mathrm{PO}_{4}$ containing |methyl-3/|inulin $(8.00(0-15.000 \mathrm{cpm} /$

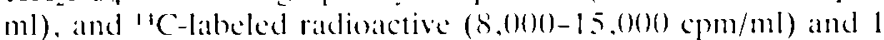
mM nonradioactive L-leucine or I)-galactose. The radionctive leucine and galactose were uniformly labeled and reported to be gor"; pure by dilution analysis, paper chromatography. and paper electrophoresis (29). The specific activities of the radioactive compounds used in this study were: L-leucine $(342 \mathrm{mCi} / \mathrm{mmol})$

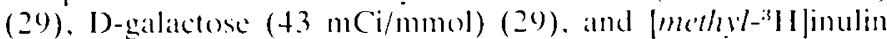
(372 m(i/mmol) (30). All common laboratory chemicals were of reagent grade quality (3!).

After incubation the segments were removed from the flasks, drained, blotted, and weighed. The residual tisste was homogenized in four times its weight of $5 \%$ trichloroacetic acid to make a $20 \% "(w / v)$ homogenate. The homogenate was centrifuged, and aliquets of the supernatant were counted in a liquid scintillation spectrometer (32) adjusted as previously described (6).

An extracellular fluid space was calculated from the distribution space of [methyl-" 11 ] inulin and expressed as a pereentage of tissue wet weight $(6,14)$. Amino acid and sugar transport values are expressed as motracellular accumulation, which is defined as the millimolar concentration of the amine acid or sugar in the cellular water after a given incubation period. This parameter was calculated on a basis of a formula by Cranc and Mandelstam (3), modified as previously described (6). A paired-difference $t$ test was ased to obtain the probability values, and a $P$ of $(0.05$ or less was interpreted ats significant (11).

\section{RISUITS}

Table 2 shows the ages and the body weights of the pups at the time of study. The offspring of females fed a $27 \%$ protein diet or an $8 " \%$ protein diet are compared. The body weights were significantly fower in the LPI) animals than in control pups at all ages studied. At 2 days of age the body weights of the LPD animals were $6.3 \%$ of those of the NPI) animals. The disparity between the weights of the animal groups increased at each age studied 
except the 28-30-day group. Interestingly, the L.PD animals followed a growth pattem similar to that of the NPD animals. albeit. a severely retarded one. The weights of the 2-day-old animals in both groups compare well with a previous study in our laboratories (6). The NPI) animal weights ate also in agreement with published data regarding the offspring of animals fed a regular rat chow (19).

Table 3 demomerates the effect of matemal diet on the intratcellular atcomulation of $1 \mathrm{~m} .1 \mathrm{I} \mathrm{L}$-ledeine in the small intestine of the developing offepring. The data compare uptake in the NPI) and L.PD pups after 5-, 1.5-, and 3(1-min incubations at the ages shown. Intracellular accumulation was significantly lower in ?day-old LPD animals at all thee incubation times by approximately the same magnitude $(18-25 \%) .1 \mathrm{~A}$ in the I.PD animals in the 14-16-daty-old period was also decreatsed 20"; compared with the NPD animals after a 5 -min incubation. At all other ages studied the IA in the LPI) animals was statistically the same or significantly increased when compared to the NPI) animals. The increase in the $\mathrm{IA}$ of L-keucine in the I.PI) animals was most dramatic in the 2()-21-day-old and the 28-30-daty-old animals. At 2()-21 dass the $1 \mathrm{~A}$ in the L.PD animals was $1.37 \%$. 144\% and $139 \%$ that in the XPD animals after incubations of 5.15 . and 30

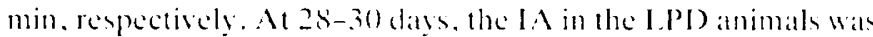
$150 \%$, that in the NPD anmals after a 5 -min incubation. $128 \%$ after a 1.5 -min incubation, and $144^{\prime} \%$ after a 30 -min incubation.

The IA results ohtained for l.-leucine in the 2-day-old animals after a s-min incubation correspond with an carlice study in our

Table 2. Effect of maternal die't on weights of developing animals

\begin{tabular}{|c|c|c|}
\hline \multirow[b]{2}{*}{$\begin{array}{l}\text { Animal ages } \\
\text { (postpartums) }\end{array}$} & \multicolumn{2}{|c|}{ Animal weights. g' } \\
\hline & $27 \%$ Protcin dict $=$ & s"; Prokin dict \\
\hline 2 Dilys & $\therefore .6 \div 01.11$ & $5.4 \div 11.4$ \\
\hline (S-9 Dats & $23.3 \pm 1.2$ & $10.4 \pm 0.4$ \\
\hline $1+-161) a 1 s$ & $28.5 \pm 11.5$ & $11.0 \pm 0.2$ \\
\hline $2(1-21$ 1)aiss & $34.5 \pm 0.5$ & $11.1 \pm 01.4$ \\
\hline $28-301$ dass & $61.3 \pm 1.5$ & $20.4 \pm 0.8$ \\
\hline
\end{tabular}

' Each value represents at lease six amimals selected randomly from at leats five litters

"Female rats were fed dich derougheut gestation and lactation. Offepring were fed dicts at weining.

3. Me:ill \pm SE:M.

4 All S'; values significantly different from 27\% values at ages comparcel, $P<0 .(101)$. laboratories using similar diets (6). The developmental pattern of $I A$ of I--leucine in the NPD animals is in agreement with results obtained from a study utilizing the offopring of females fed a standard lab rat chow (7).

The effect of maternal diet on the intracellubar accumulation of $1 \mathrm{mMl} \mathrm{D}$-galactose in the developing intestine of the offepring of females fed a $27 \%$ protein (NPI)) or $S^{\prime \prime} "$ protein (LPD) diet is demonstrated in Table 4 . At 2 and $8-9$ dats of age, $1 x$ in the LPI animals was significantly lower than in the NPI) animals at all incubation times. The decrease was approximately 20 " in the 2-day-old animals and $11 \%$ in the $8-9$-day-old animals at all incubation times studied. In both age groups the decrease was greatest after 5-min incubations. In the 14-16-day-old animals. IA was not statistically different in the diet groups. At 20)-21 and $28-30$ days of age the $I A$ of $1 \mathrm{mII}$ D-galactose in the I.PI) animals was the same as that in the NPI animals after at 5 -min incubation and increased all alverage of $35 \%$ with the longer incubation periods.

The $1 \mathrm{~A}$ of $\mathrm{D}$-galactose in 2-day-old animal intestincs after at 5 min incubation agrees with our earlice study (6). The developmental pattern for the NPI animals corresponds with previous studies (2.7).

\section{I)IS( $\operatorname{cossion}$}

The purpose of this study was to examine the effect of the matemal diet on the development of intestinal tramsport in their offspring. Alterations in the developmental patterns of intestinal transport of L-kedeine and D-galactose in the offepring of females fed a low protein diet as compared to the offspring of females fed a control protein diet were demonstrated. The in ritro method employed allowed us to compare the intracellular accumulation (IS) of Leu and (Bal at various incubation times which include initial velocities $(5 \mathrm{~min})$. as well as steady state conditions (30 min) (13).

In this study the developmental patterns for the intracellular accumulation of 1 ecu and (ial vary between diet groups at intial velecities (compare Tables 3 and 4 . 5-min incubations). At 2 days postpartum, the $1 . A$ of 1 -cu and (sal after a 5 -min incubation are significantly reduced in the intestines of tie L.PI) animals as compared to the NPD andmals. However. in the $8-9$-dity-old animals the $I .4$ of $l$ enu is statistically the same for both animal groups while the $A$ of Gal is decreased significantly in the I.PI) animals as compared to the controls. At it-16 days of age the IA of 1 ecu is decreased in the l.PD animals as compared to the

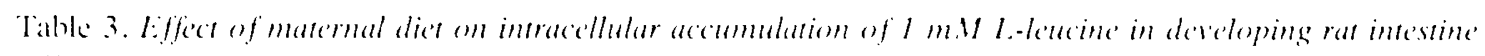

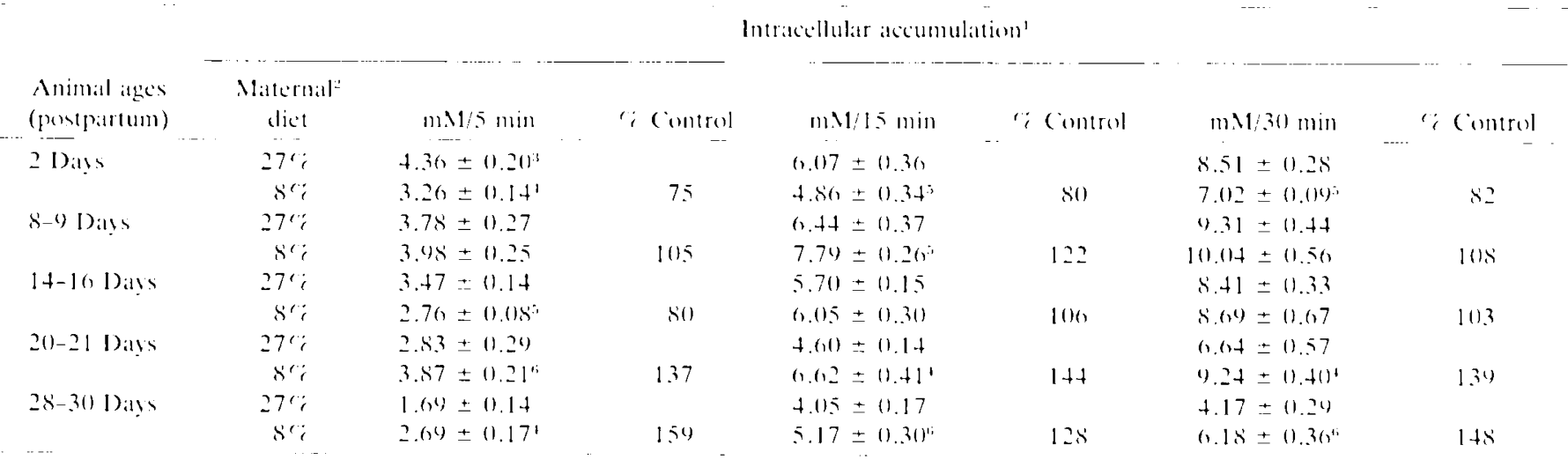

'Each value represents at least six experiments cach using one intestinal segment from ome rat. Animals were selected randeml! from at least five different litters in each diet group.

"Female rats were fed diets throughout gestation and latetation. Offepring were fed diets at weaning. $27 \%$ : $27 \%$ protein diet (mormal comtrol): $8 \%:$ : sei protein dict (low).

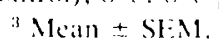

+ Significantly different from $27 \%$ diet group. $P=0.01$.

"Significantly different from $27 \%$, dict group, $P<0.001$

"Significantly different from $27 "$ " diet group, $P \Leftrightarrow 0.02$. 
Table +. Effect of maternal diet on intracellular accumulation of $1 \mathrm{m.M} \mathrm{l}$ )-galactose in de'seloping rat intestime

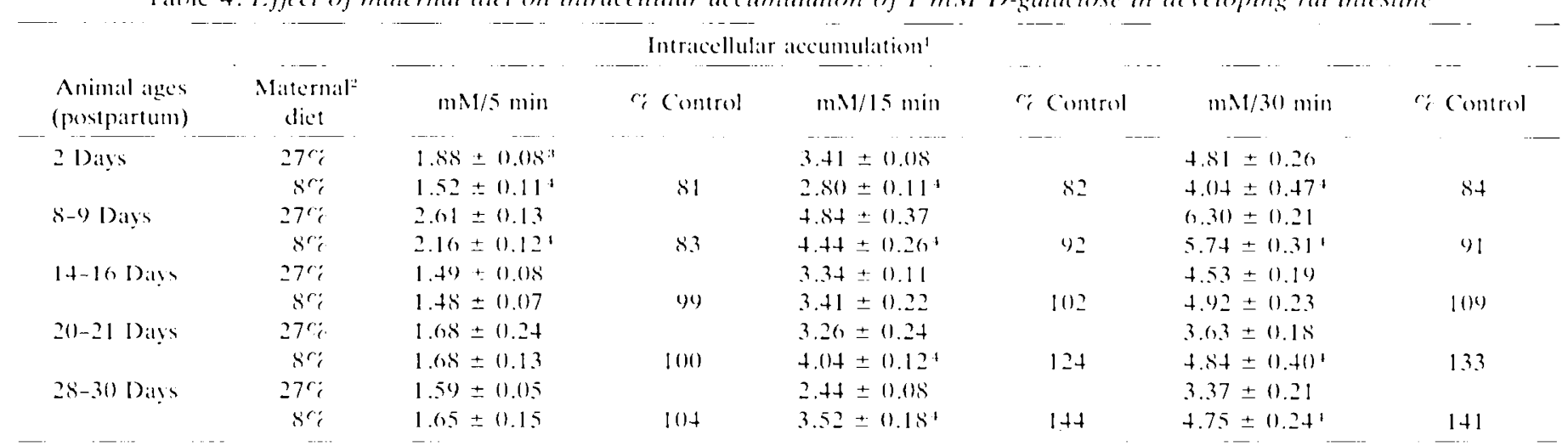

1 Each value represents at least six experiments each using one intestinal segment from one ratt. Animals were selected randomly from at least five differeme litters in each dict group.

"Female rats were fed diets throughout gestation and lactation. Offspring were fed dicts at weaning. 27\%": $27 \%$ protein diet (normal control): $8 \%$ : $8 \%$; control diet (low).

"Mean \pm SLIS.

4 Signilicintly different from $27 \%$; dict group. $P<0.05$.

NPI) controls, whereas the $1 \mathrm{~A}$ of Gal is the sime in both groups at initial velecities. At 20-21 and $28-30$ days of age, the percentage $I A$ of $L$ ecu is significantly increased in the LPI) animals as compared to the NPI animals. These pereentages also reflect a decrease in the $\mathrm{I} A$ of $\mathrm{lecu}$ in the control animals. At 20-21 days the $I A$ of Gal after a 5 -min incubation wats the same in both diet groups.

After 15-min and 30-min incubations (compare Tables 3 and 4) the IA of leu wals decreased in the 2-dily-old L.PI) animals ats compared te controls. At all other age periods, the IA values for Led after 15 -min and 30 -min incubations were similar in both diet groups or showed a pereentage increase in the LPD animals. At steady state conditions (3()-min incubation) this increase was significant at 20-21 and 28-30 dats of age. The IA of (Bal Wats decreased in the L.PI) animals as compared to the controls in the 2- and 8-9-day-old groups alter 15 - and 30 -min incubations. In 14-16-day-old animals. the 11 of (iat was similar in both diet groups after $3(0-\mathrm{min}$ incubations. Howerer, the IA of (ial in the L.PI) animals was significantly increased at $20-21$ and $28-30$ dats of age at steady state conditions.

The selective variations in the developmental patterns of the IA of $L$ eeu and Gal in the intestines of $\mathrm{L}$.PD animals as compared to NPD animals observed in these studies appear to be related to animal age and incubation time. At $20-21$ and $28-30$ days of age. the redative $I A$ of Leu is increased in the L.PI) animals as compared to the NPI) animals at intial velocities and steaty state conditions: the IA of (ial in the I.PI) animals is maintaned at the same level as the controls at initial velocities, and increatsed relative w the NPI) animals at steadly state conditions. An increased transport of carbohydrates in semistarved animals (5) and growth-retarded suckling rat pups (23) has been attributed to thinner gut walls as a conseguence of dietary deficiency. Mindmarsh de al. (s). using everted intestinal sacs from semistarved animals, demonstrated that changes in intestinal wall thickness were not sufficient to account for the observed increase in the transport of glucose and histidine. Further. Wapnir and Lifshitz (1s) have shown selective alterations in amino acid transport in malnourished animals. In the present study, a retarded weight curve was evident in the suchling goung of malnourished females (sec Table 2). It is interesting. however, that relative increases in intracellular alccumulation ereur after weaning $(20-21628-30$ days) in the I.PI) animals when a doubling of body weight is demonstrated. The natural food of mammals during the suckling period is milk. Maternal malnutrition has been shown to negatively affect lactation and thereby reduce the amount of milk available to the offopring $(4,12)$. It is possible that the availability of solid food ad libimm from the weaning period ( $18-21$ days) through the rest of our study (2s-30 days) has influeneed the results and that the observed improvement in transport reflects an improved caloric intake even though the diet for the l.PD animals continued to he relatively protein deficiont. Previous studies have deseribed a decrease in gut size and intestinal eell numbers in malnourished animals (16, 23, 24). Recent studies of catch-up growth in malnourished animals hate demonstratted a partial relabilitation in body size and weight parameters when the animals were fed nomal diets al weaning (20. 21). Thus the values obtained in these studies maty reflect an increase in gut maturation with more sites avatiable for tramport. Our data do not preclude the possibility that the 1.PD animals have an increased affinity for the substrate between 2021 and $28-30$ days of age as compared to the NPI) animals. Indeed. multiple factors including gut stee. cell numbers, anailable transport sites, and affinity must contribute to the overall developmental pattern of intracellualar accumulation in malnourished animals and must be considered in drawing correlations between the malnourished amimal mokel and malnourished infant.

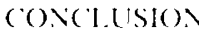

Pregnant rats were fed a $27 \%$; protein diet or an s'"; protein diet throughout gestation and lactation. The in sitro absorptive capacity of the offspring was studied hy measuring the intracellalar accumulation of L-leucine and D-galactose. The absorption of both compounds was decreased at 2 dats of age in the offspring of the females fed the s"y protein diet ats compatred to the offepring of the females fed the $27 \%$ protein diet. Inowever. by the weaning period the low protein diet animals cxhibited an increased ability to absorh I--keucine and I)-gallactose which was equal to or greatter than that of the control animals.

\section{RIETERINCHS ANI) NOIIS}

1. Adibi, S.. and Allen, I:. R.: Impaired jejunal aburption rates of enential amino acids induced be cither dictary calorie or protein deprivation in man. (iastroenterolons $50: 404(19711)$.

2. Bamford, D. R., and lngham. P. A.: Sugar ahorption he foctal and neonatal rat intentinc in vitro. J. Physiol.. 275: 335 (1975).

3. Crane, R. K. and Mandelatam, P.: The active trampert of sugars by various

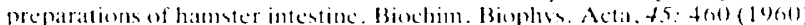

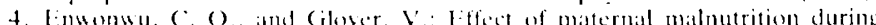
pregnancy and lactation on hepatic protein metaholiom in the infant rat: biochemical and ultrantructural studies. Amer. J. (lin. Nutr.. 20: 3 (197.3)

5. Esposito, G.: Intestinal aborption of sugars in semi-starved rats. Proc. Soc 
Exp. Biol. Med., 125: 452 (1967)

6. Fitzgerald, J. F., and Ferdinandus, L. D.: Effect of maternal protein deprivation on in vitro neonatal intestinal function in rats. J. Nutr., 105: 1476 (1975).

7. Fitzgerald, J. F., Reiser, S., and Christiansen, P. A.: Developmental pattern of sugar and amino acid transport in the postnatial rat small intestine. Pediat. Res., 5: 698 (1971)

8. Hindmarsh, J. T., Kilby, D., Ross, B., and Wiseman, G.: Further studies on intestinal active transport during semistarvation. J. Physiol., 188: 207 (1967).

9. James, W. P. T.: Intestinal absorption in protein-calorie malnutrition. Lancet, 1: $3.33(1968)$

10. James, W. P. T.: Sugar ahsorption and intestinal mobility in children when malnourished and after treatment. Clin. Sci., 39: 305 (1970).

11. Natrella. M. G.: Experimental statistics. In: Burcau of Standards. Handbook 91 , p. 3 (Washington, D.C.. 1963).

12. Perisse, J., and Salmon-Legagneur, F.: Influence of the nutrition level in the course of pregnancy and lactation on milk production of the rat. Arch. Sci. Physiol., 14: 105 (1960)

13. Reiser, S., Fitzgerald, J. F., and Christiansen, P. A.: Kinctics of the accelerated intestinal valine transport in 2 day old rats. Biochim. Biophys. Acta, 203: 351 (1970)

14. Rosenberg, L. E., Downing, S. G., and Segal, S.: Extracellular space estimation in rat kidncy slices using ${ }^{\prime \prime}$ saccharides and phlorizin. Amer. J. Physiol., 202: 800 (1962).

15. Sachs, B.: Maternal nutrition-what price? New Engl. J. Med.. 292: 20s (1975).

16. Shrader, R. E., and Zeman, F. J.: Effect of maternal protein deprivation on morphological and enzymatic development of neonatal rat tissue. J. Nutr. 99: $401(1969)$.

17. Torres-Pinedo, R., Rivera, C.. and Rodrique\%, H.: Intestinal absorptive defects associated with enteric infections in infants. Ann. N. Y. Acad. Sci.. 176: $28+4$ (1971)

18. Wapnir, R. A., and Lifshitz, F.: Absorption of amino acids in malnourished rats. J. Nutr., 104: $8+3(1974)$
19. Weber, G., Queener, S. F., and Ferdinandus, J. A.: Control of gene expression in carbohydrate, pyrimidine and DNA metabolism. Advan. Enzyme Regul., 9: 63 (1971).

20. Williams, J. P. G., Tanner, J. M., and Hughes, P. C. R.: Catch-up growth in male rats after growth retardation during the suckling period. Pediat. Res.. $8: 1+9(1974)$.

21. Williams, J. P. G., Tanner, J. M., and Hughes, P. C. R.: Catch-up growth in female rats after growth retardation during the suckling period: comparison with males. Pediat. Res., s: 157 (1974).

22. Winick. M1.: Biological correlations. Amer. J. Dis. Child., 120: 416 (1970).

23. Younoszai, M. K., and Lynch, A.: In vivo intestinal absorption of hexose in growth-retarded suckling rat pups. J. Nutr.. 10.4: 671 (1974).

24. Younoszai, M. K., and Ranshaw, J.: Gastrointestinal growth in the fetus and suckling rat pups: Effect of maternal dietary protein. J. Nutr., 103: 454 $(1473)$.

25. Zeman, $\mathrm{F}$. J.: Iffect on the young rat of maternal protein restriction. J. Nutr., 93: $167(1967)$

26. Harlan Industries, Inc., Indianapolis, Ind.

27. Lab Blocks. Wayne Feeds, Castleton, Ind

28. Tek-Lad Test Diets, Madison, Wisc.

29. Amersham/Searle Corporation, Arlington Iteights, III.

30. New England Nuclear, Boston. Mass.

31. Sigma Chemical Co., St. Louis, Mo.

32. Tri-Carb liquid scintillation spectrometer model 3320, Packard Instrument, Downers Grove, Ill.

33. The authors would like to thank the Laboratory Animal Medicine Prowram for their assistance in the maintenance and care of the animals used in this study. The authors are deeply indebted to Vicki llaviland for assistance in the preparation of this manuscript.

34. This research was supported by Riley Memorial Association, Project 75-7.

35. Requests for reprints should be addressed to: J. F. Fitzgerald, M.D., Department of Pediatrics, Gastrointestinal Disease Section, Indiana University Medical Center, 1100 W. Michigan St., Indianapolis, Ind. 46202 (USA)

36. Received for publication June 25, 1976

37. Accepted for publication November 23,1976

\title{
A Paper Chromatoelectrophoresis Method for the Determination of Bilirubin Binding to Serum Protein
}

\author{
EUGENE AINBENDER, "21) EDWIN G. BROWN, YUN J. LEE, AND AVRON Y. SWEET \\ Department of Pediatrics, Monte Sinai School of Medicine' of the City University of New York, New York, New. \\ York, USA
}

\begin{abstract}
Summary
A technique is described in which paper chromatoelectrophoresis is used to measure the bilirubin binding capacity of albumin in serum. It is equivalent to the Sephadex G-25 method and its results are highly reproducible. From a single pool of serum, multiple determinations indicated the mean bilirubin binding capacity to be $23.7 \pm 0.76(S D) \mathrm{mg} / \mathrm{dl}$ and the greatest difference between any two values was $2 \mathrm{mg} / \mathrm{dl}$. This new technique can determine the bilirubin binding capacity of a serum sample in $15 \mathrm{~min}$. Highly skilled technicians are not needed and very small quantities of serum are required, which gives it a definite advantage over the Sephadex G-25 method.
\end{abstract}

\section{Speculation}

Paper chromatoelectrophoresis is a simple, rapid, and inexpensive technique which can be used to measure the bilirubin binding capacity in very small volumes of serum. It appears to have sufficient accuracy and reliability to be applied as a clinical guide to the severity of unconjugated (indirect acting) hyperbilirubinemia in the newborn infant. If further experience with the method supports this report, decisions regarding phototherapy and exchange transfusion to treat infants with unconjugated hyperbilirubinemia might be made on a more rational basis.

The technique could be made much more sensitive by using radioactive bilirubin. In this way, if could become a useful research tool in the study of bilirubin metabolism.

Serum unconjugated (indirect acting) bilirubin that is not bound to albumin is a cytotoxin $(6,16)$. It has been assumed that unbound bilirubin is responsible for bilirubin encephalopathy (14). There are several common problems of newborn infants that result in marked unconjugated hyperbilirubinemia and because there are therapeutic measures available to prevent biliru- 